\title{
Tropical Dry Forest Diversity, Climatic Response, and Resilience in a Changing Climate
}

\author{
Kayla Stan $(\mathbb{D}$ and Arturo Sanchez-Azofeifa *(D) \\ Department of Earth and Atmospheric Sciences, University of Alberta, 1-26 Earth Sciences Building, \\ Edmonton, AB T6G 2E7, Canada; stan@ualberta.ca \\ * Correspondence: arturo.sanchez@ualberta.ca; Tel.: +1-780-492-1822
}

Received: 9 April 2019; Accepted: 22 May 2019; Published: 23 May 2019

\begin{abstract}
Central and South America tropical dry forest (TDF) is a water-limited biome with a high number of endemic species and numerous ecosystem services which has experienced a boom in research in the last decade. Although the number of case studies across these seasonal, water-limited, tropical forests has increased, there has not been a comprehensive review to assess the physiological variability of this biome across the continent and assess how these forests respond to climatic variables. Additionally, understanding forest change and resilience under climatic variability, currently and in the future, is essential for assessing the future extent and health of forests in the future. Therefore, the objective of this paper is to provide a literature review on the variability of TDF diversity and structure across a latitudinal gradient and to assess how these components respond to differences in climatic variables across this geographic area. We first assess the current state of understanding of the structure, biomass, phenological cycles, and successional stages across the latitudinal gradient. We subsequently review the response of these five areas to differences in precipitation, temperature, and extreme weather events, such as droughts and hurricanes. We find that there is a range of adaptability to precipitation, with many areas exhibiting drought tolerance except under the most extreme circumstances, while being susceptible to damage from increased extreme precipitation events. Finally, we use this climatic response to provide a commentary on the projected resilience of TDFs under climatic changes, finding a likelihood of resilience under drying scenarios, although model projections do not agree on the magnitude or direction of precipitation change. This review of quantitative studies will provide more concrete details on the current diversity that encompasses the $\mathrm{TDF}$, the natural climatic ranges under which this ecosystem can survive and thrive, and can help inform future forest management practices under climate change scenarios.
\end{abstract}

Keywords: biomass; climate change; drought tolerance; forest structure; resilience; succession; tropical dry forests; water use efficiency

\section{Introduction}

Changes in climate are heavily impacting both natural and developed areas in Central and South America [1-3]. Over the past five decades, climatic phenomena have been responsible for 88 percent of disasters, globally [4]. These climatic disasters include increases in hurricanes and tropical storms in areas that have previously not seen this scale of storm, as well as increases in droughts and flooding due to extreme El Niño and La Niña events $[1,2,5,6]$. Climatic changes have impacted biomes around the globe, with recent increases in disturbance decreasing ecosystem recovery rates and variations to precipitation and temperature which directly impacts forest phenology, flowering rates and times, photosynthesis, water use, and nutrient transport. The changes that occur in tropical dry forests (TDFs) is of particular interest as the countries in which they are located house high population densities and much of the forest is converted for agriculture and cattle $[7,8]$. 
TDFs encompass $42 \%$ of the tropical forest regions and have focal points in Central and South America, Africa, Central Asia, India, and Australia [8-10]. Only 2\% of the TDFs are intact and only 8\% are legally protected $[7,10]$, but they contain high levels of biodiversity, with 12 distinct floristic groups in the Central and South American TDF and the number of unique tree species in stands ranging from 100 at high latitudes to over 1000 near the equator [11-13]. Additionally, between 50\% and 75\% of the remaining TDF is thought to be located in Central and South America, predominantly in Mexico, Bolivia, and Brazil [14,15] (Figure 1). An area with a mean annual temperature $>25^{\circ} \mathrm{C}$, precipitation between 700-2000 mm with a dry season of $<100 \mathrm{~mm}$ for at least three months, which comprises $>50 \%$ deciduous trees, defines the TDF ecosystem [16]. Additionally, TDFs are water-limited and have high biodiversity typified by trees, lianas, shrubs, herbs, graminoids, and bromeliads [17].

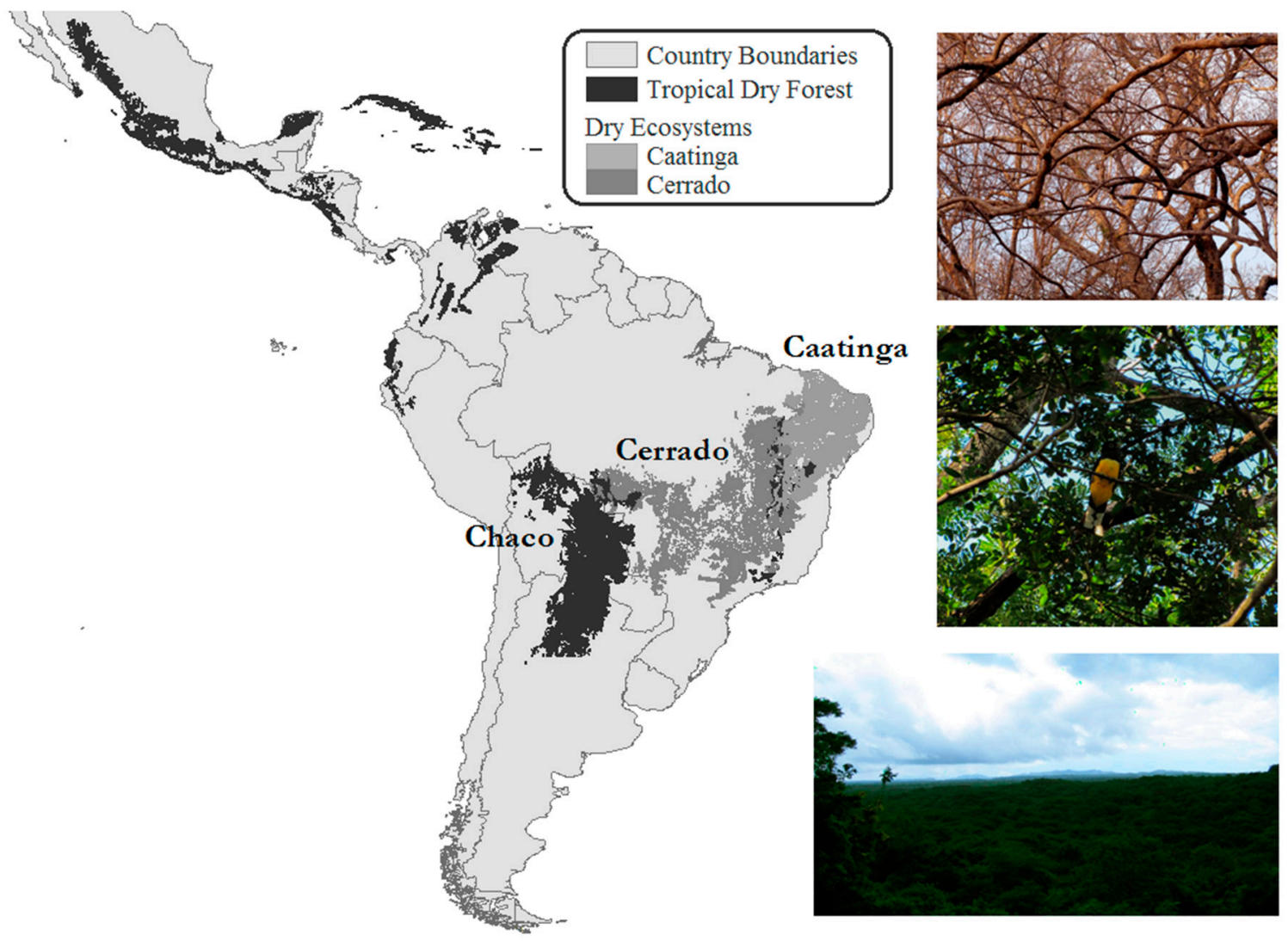

Figure 1. Location of the tropical dry forests (TDFs) in Central and South America. The dry ecosystems also include the Brazilian Cerrado (savanna) and Caatinga (Data from Portillo-Quintero and Sanchez-Azofeifa 2010; photos from Antonio Guzman Quesada).

Tropical dry forests have the third highest deforestation rate globally and are subject to high anthropogenic alteration [14,18,19]. Much of this deforestation is due to high population densities, which creates a predominantly fragmented landscape [14,20]. The high population densities in TDFs are due to climate, geography, and a high number of neotropical freshwater sources [21]; however, despite its regional and global importance, it remains severely under-studied relative to the humid forest [22]. Only 14\% of tropical forest scientific papers, until 2005, focused on tropical dry forests, with a heavy emphasis on Costa Rica, Mexico, and Brazil [14,16,23]. Since 2005, research into TDFs has been increasing but it still only comprises less than $25 \%$ of research into tropical forests annually (Figure 2 ). 


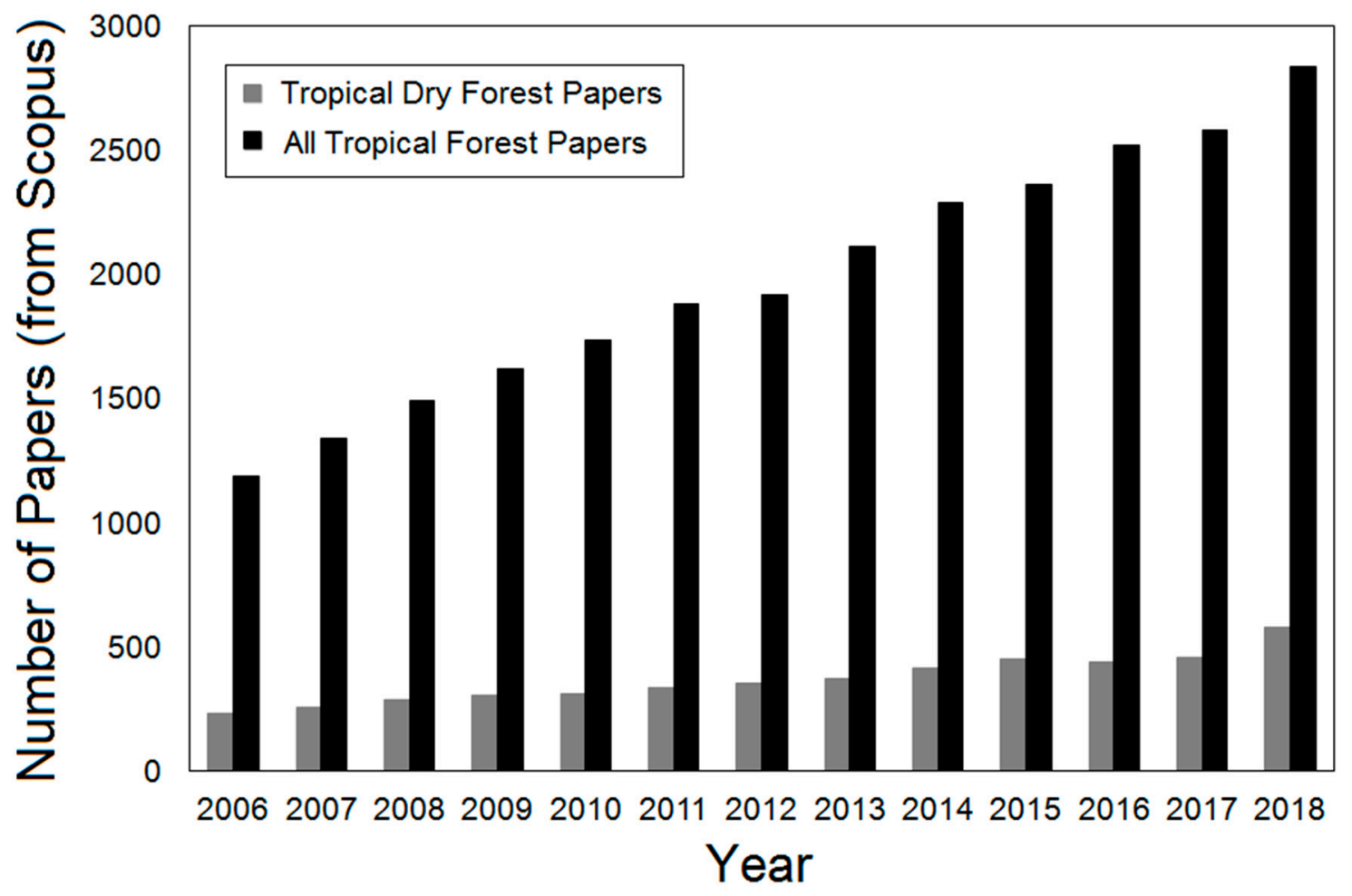

Figure 2. The number of papers on tropical forests and TDFs annually from 2006 to 2018 based on Scopus search results.

Much of the TDFs in Central and South America remain unprotected, highly fragmented, and at risk of being cleared [14]. In Brazil, for example, more than $90 \%$ is comprised of secondary forests, which have recovered after being cleared or burned for agriculture [19,24]. In contrast, Costa Rica is an exception where legislative, social, and economic changes have led to regeneration rates exceeding current deforestation rates $[25,26]$. Conservation strategies, aimed to protect TDFs in different countries have ranged from the implementation of payments for ecosystem services to the creation of conservation areas and community-based management systems [25,27]. The degradation and anthropogenic protections detailed above do not take into account forest alteration under climatic change. With an uncertain future in temperature and precipitation regimes in a highly populated and fragmented ecosystem, it is essential to understand the relationship between the TDF ecosystem and climatic variables and how they respond under natural stresses.

Scientific reviews dealing with TDF biomass and resilience came out in 2012 [28], 2016 [11], and 2017 [29]. Becknell et al. [28] focused on above-ground biomass of mature and secondary dry forests around the globe, with no discussion of the climatic impact on the structure, successional stages, and phenological cycles. While a discussion of correlations with precipitation was present, there was no consideration for extreme climatic events, or the effects of temperature, which ultimately impact the water available to ecosystems. Banda-R et al. [11] extensively reviewed the diversity of Neotropical dry forests, with similarity analyses, and the categorization of TDF sites into 12 major floristic groups. Allen et al. [29] wrote a predominantly qualitative review which focused on below-ground biomass and the impact of drought on TDF root systems. None of these reviews, however, discuss the effects of climate variability and climate change on TDFs [11,28,29].

Here we review the tropical dry forest across Central and South America in terms of successional stages, forest structure, above-ground biomass, and phenology. Additionally, we discuss the response of these TDF features to changes in climate, including precipitation, temperature, and extreme events, and assess the potential resilience of TDFs using these parameters for projections of future climatic change. 


\section{Components of Tropical Dry Forests}

\subsection{Forest Dynamics}

Forest dynamics describe how forests grow, change, and react to environmental pressures, with key components of tree mortality, growth, and recruitment [30,31]. Anthropogenic influences, especially agricultural activities, are the primary cause of tropical dry forest alteration. Land abandonment leads to the growth of secondary TDFs interspersed with primary old growth forests as documented in Costa Rica [32,33]. The methodology that is most appropriate to study and group successional stages is disputed, with long-term studies, palynology, chronosequences, and stand reconstruction all suggested as best practices $[9,34]$. Chronosequences, or grouping stages into early, intermediate, and late-stage based mainly on time since abandonment, is one of the most common study methods but has also garnered criticism because it assumes a consistent history between different locations [9,35-37]. Despite the criticism of chronosequence analysis of successional stages, the replication it provides and its ability to capture TDF heterogeneity make it the most feasible procedure for studying its rapidly changing dynamics [9]. The structure of the forests, both horizontally and vertically, also defines successional stages. In early-stage succession, there is a matrix of seedlings, herbs, grasses, and sparse woody vegetation [14,17]. As succession progresses, there is a higher proportion of trees, shrubs, and bromeliads, the increased presence of lianas, and canopy coverage of $63 \%-80 \%$ [17,38]. The intermediate stage typically has the highest net primary productivity and species richness, as well as the highest density of lianas $[17,39,40]$. Late stage forests, however, are typically considered to have the highest species evenness $[9,19,40]$ (Figure 3). Later successional stages also exhibit reduced regeneration capabilities as there is less sapling recruitment in stands $>15$ years old, resulting in slower recovery from events and slower species turnover [17,39].

Recruitment rates are highest in early stage forests, although climate moderates these rates $[17,38,39]$. In Mexican sites, there is reduced recruitment and sapling development in wetter years thought to be due to reduced flowering and seed production in nearby stands compared to dry years $[38,41,42]$. This trend is also replicated in shrubs, which is problematic for the recruitment of and subsequent biomass growth of pioneer species in newly abandoned pastures $[38,43,44]$.
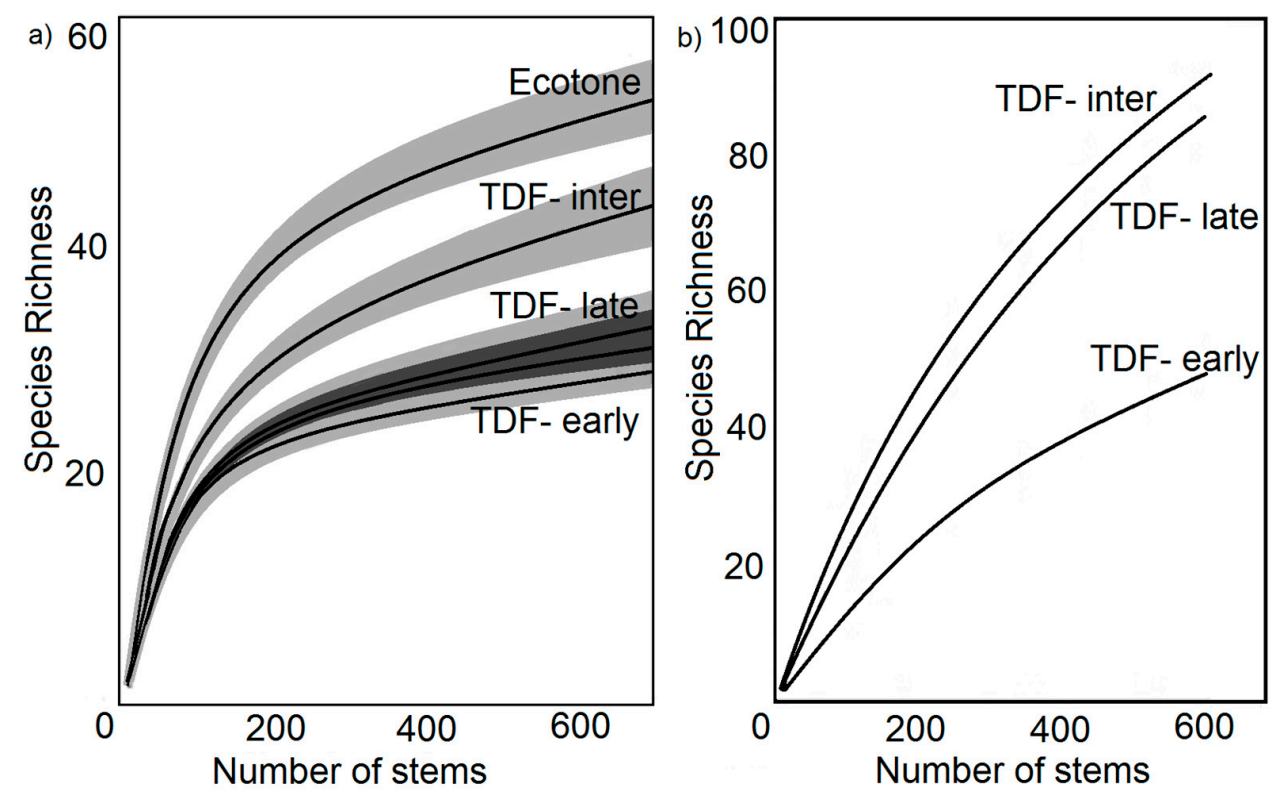

Figure 3. Species richness and the number of stems by successional stage reproduced from Minas Gerais, Brazil as found in Coelho et al. (a) [19] and from Santa Rosa National Park, Costa Rica, based on data from Kalacska et al. (b) [45]. Intermediate stage TDFs have the highest species richness of the secondary TDFs. The ecotone consists of a combination of primary TDF and savanna land. 
The previous land use of secondary TDFs and individual site characteristics are impactful for the resulting species recruitment rate, diversity, and mortality [40]. Plots with a history of use as cultivated lands had a significantly lower species evenness and slower recruitment rates when compared to plots with a history of being used as unmanaged pasture land [40]. In Costa Rica, pasture sites had a much lower rate of species recruitment compared to low-intensity use plots, and site-specific conditions, such as proximity to seed sources were highly impactful for plot structure and diversity [37]. Seed sources from proximal old growth forests also tend to drive the eventual species makeup of the secondary forest $[40,46]$. In all Costa Rican successional stages, the most abundant species are dispersed by either wind or by animals, particularly birds [13,47].

Additionally, many species are unique to a single successional stage, irrespective of latitude. In Brazil, only $13.5 \%$ of species were common across all successional stages, with $43.2 \%$ of species unique to only one successional stage [19]. A similar trend occurs in Costa Rican sites, $18 \%$ of species found in all forest plots, and $48 \%$ unique to a single site, with $19 \%$ represented by only by a single individual [13].

Overall, the literature characterizes the successional stages of tropical dry forests, across the entire latitudinal gradient, into early, intermediate, and late stages by age, with some research, also distinguishing primary forests as a separate class. As succession increases, each stage has a more complex composition and structure, although some factors such as primary productivity are highest in intermediate forests across the Neotropics. Finally, across all the Central and South American TDFs, recruitment rates, and regenerative capabilities decrease as successional stage increases.

\subsection{Forest Structure}

Forest structure is highly dependent on forest age and the level of disturbance in both primary and secondary forests. In general, the measurable structure in a forest can be broken up into stem density, basal area, number of canopy levels, and in the case of tropical dry forests, liana infestation [15].

Stem density in TDFs is highly variable across the continent and between plots. In Brazil, early stages have the lowest stem density and late-stage the highest, with small diameter trees most prevalent in the intermediate stages [19,35]. In Bolivia, stem density is most variable in the late-stage [17], while these young forests have a greater abundance of small stems, as well as a low canopy cover [17], which allows for higher herb and grass abundance in early successional stages. North of the equator, in Mexico, the density of stems with the diameter at breast height (DBH) between $0.10-0.30 \mathrm{~m}$ varied by plot, but typically decreased with stand age. Furthermore, the density of stems $>0.30 \mathrm{~m}$ increased asymptotically with stand age. Stem density is also impacted by the underlying geomorphology, with ridgelines and low slopes having a higher stem density in Mexican sites compared to regions with intermediate slopes [48]. In Venezuela, stem density is the lowest compared to all other biomes, except the plains, and the basal area is third smallest above only the plains (i.e., Llanos) and the mid-elevation Andean forest [49].

The basal area and DBH of successional stages also varies across the continent. As the successional stage increases, the basal area of plants increases in the Southern Hemisphere [17,19]. In the Northern Hemisphere, a local-level analysis found that the Yucatan has a smaller basal area compared to other TDF sites across Mesoamerica and that secondary forests never recovered a basal area comparable to the primary mature forests [39]. Slopes impact the basal area of tree stems with the total basal area increasing from $20.84 \mathrm{~m}^{3} /$ ha to $27.06 \mathrm{~m}^{3} /$ ha from the ridgeline to the lower slopes, respectively, in Chamela, Mexico [48].

Liana infestations, more common in disturbed areas, also have a spatial structure component, and impact the resulting forest structure by negatively affecting the basal area and DBH in infested forests [50,51]. Lianas in Bolivia can cover between $8 \%-15 \%$ of stands [17], although the density of vines correlates to the level of disturbance in a patch [52]. The higher abundance of TDF lianas compared to wet and moist forests is thought to be due to liana advantages in the dry season, including a faster green-up, slower senescence, the heightened solar radiation in arid forest zones, and the greater 
availability of this radiation throughout the year [51,53-55]. Additionally, liana presence is highly correlated to elevation, with sharp declines in liana presence above 1000 masl [51,56].

Overall, late-stage forests in Yucatan, Mexico have the smallest basal area, followed closely by Brazil and Venezuela, while both Chamela, Mexico, and Bolivia have the largest basal area $[17,19,39,48,49]$. Instead of a latitudinal gradient, studies appear to find that areas closer to the Pacific have a smaller overall basal area. Stem density did not show a consistent pattern across the continent, varying widely between successional stages and individual plots [17,19,35,48,49]. Liana infestations follow a different pattern entirely, more closely associated with disturbance, rainfall, and elevation.

\subsection{Phenological Cycles}

TDFs of the Neotropics have a mix of deciduous and evergreen species, with at least $50 \%$ of the species exhibiting a deciduous nature [16]. The phenology of the TDF, seasonal cycles of the expression in TDFs, include periods of tree growth and dormancy, green-up and senescence, flowering, and fruiting [57]. In TDFs, these patterns are driven by seasonal patterns variations in precipitation with the wet season bringing green-up and growth and the dry season resulting in senescence and dormancy [57]. This phenological cycle and its variation across latitudinal gradients have been identified as essential for proper classification of the dry forest and as a research priority; however, there is still a significant gap in the direct quantification of its phenological signature [14-16,21]. Additionally, remote sensing of phenological components, such as green-up, is not accurate, with a 1-3 week discrepancy between satellite and in situ data for the start of green-up. Satellite data, instead, corresponds to the peak rate of change in the green-up [58].

In the few studies that have analyzed this pattern, the level of deciduous species is thought to be related to the duration and severity of the dry season, variability in soil moisture, and micro-scale environmental conditions including rooting depth, temperature, and plant available water content $[14,41,59,60]$. Additionally, there are differences in phenological cycles across countries and successional stages. Leafing intensity for early successional stages during the dry season and at the beginning of the rainy season is highest away from the equator (Mexico and Brazil), while it is reduced in equatorial regions (Costa Rica) [61]. In Costa Rica, the total phenological cycle varies between 150-358 days, depending on the presence of late-season rains, which extends the forests' maturity period [62]. Leafing intensity between successional stages is not significantly different; however, there are significant differences in the number of species that have $50 \%-100 \%$ of their leaves in the Brazilian and Costa Rican rainy seasons between stages [61]. Under drier conditions, all stages experience earlier senescence; however, increased senescent individuals is gradual in the early stages but abruptly changes in intermediate and late stage forests [63].

\subsection{Above-Ground Biomass (AGB)}

On a continental scale, there is a latitudinal gradient both in the current aboveground biomass and the potential AGB. AGB is a measure of all living plant mass that is located above the ground [64]. Mass from stems, leaves, seeds, branches, and bark [64]. These values are directly correlated to precipitation values and the number of dry season months [28]. Mexico and Brazil are found to have the lowest biomass present, while the highest values are found in Costa Rica [28]. The potential for the recovery of AGB is vital in secondary TDFs, and the highest potential ABG resides in the central latitudes, with lower values away from the equator [65]. Tree growth and mortality drive biomass change between years (i.e., the potential for biomass). Tree mortality in early stage TDF is quite small; however, this rate increases to a level comparable to wet forests in late successional stages [66]. This low mortality among early TDF stages reduces species turnover and the rate of AGB accumulation in these forests [66].

There is no consistent difference between the AGB in TDFs and nearby moist forests. Some studies find TDF sites with far less AGB than floodplain forests, but 3-4 times more when compared to pastures $[48,67]$. In Mexico, ABG varied across latitudinal gradients and between successional stages 
but had only $25 \%$ of the biomass when compared against the values found in the same stages of wet forests [66]. There is a similar situation in Venezuela where TDFs exhibit the lowest biomass of all biomes [49]; however, this is not consistently replicated by other studies which finds that TDFs have a much higher biomass compared to rainforests of a similar age [68-73]. The types of plants that contribute the most to biomass also differ between wet and TDFs. In the TDF, the contribution of multi-stemmed individuals was higher than moist forests (45.8\%-56\% of the AGB) [66].

In Mexico, the AGB is typically dependent on a few select species, although the exact composition is site dependent. Some sites have $80 \%$ of the AGB explained by two species from the Mimosa genus (Mimosa acantholoba var. and Mimosa tenuiflora), while others have eight species accounting for the same biomass [66]. The Chamela Biological Station (Jalisco, Mexico) has the most number of species accounting for AGB at 16-17 species [66]. On a micro level, these differences could be due to the factors impacting the forest growth and development, with the variability in AGB in Southern Mexico predicted by the distance to streams, solar irradiance, and altitude [74] in some sites and elevation and slopes found as the most important in other plots [48].

Despite micro-scale variations in above-ground biomass, which are driven by species composition and micro topographical features, there is an overall continental latitudinal trend in above-ground biomass. The above-ground biomass is, in general, highest in the equatorial regions, and reduces moving farther away from the equator [49,66,68-73]. Much of the current AGB and growth research uses traditional forest inventories; however, dendrochronological methodologies have recently been used to more accurately describe growth patterns at a fine temporal resolution in the boreal forests $[75,76]$. These approaches could be transferred to TDF regions to explore their growth response and incorporate them into non-linear models $[75,76]$.

\subsection{Biodiversity}

Much like the AGB, there are latitudinal trends in the species diversity found across TDFs, although micro-scale differences moderate this effect. Overall, species diversity is lower away from the equator, with plots in Mexico and Brazil typically having 90-100 flora species [39,77], and equatorial latitudes having much higher diversity. In Costa Rica, plots had over 135 tree species alone and in Panamanian sites, it is estimated that there are over 1000 flora species $[12,13]$. Both near the equator and at higher latitudes there are typically more species that are only common to a single plot or successional stage in the TDFs. In Brazil, only $13.5 \%$ of species were common across all successional stages, with $43.2 \%$ of species unique to only one successional stage [19]. A similar trend occurs in Costa Rican sites, $18 \%$ of species found in all forest plots and $48 \%$ unique to a single site, with $19 \%$ represented by only by a single individual [13].

Species composition also differs by country. In Brazil, Fabaceae was the most speciose of the families $[19,77]$. The family accounted for $25 \%$ of the species in the early stage, $41.5 \%$ of the intermediate stage, and $21.4 \%$ of the late stage. The family with the highest number of individuals, however, was the Anacardiaceae family, accounting for $50 \%$ and $25 \%$ of individuals, respectively, for late and intermediate stage sites, respectively [19]. In Costa Rica, however, there was a wider range of abundant species depending on the location and successional stage of the plot. In general, Quercus oleoides, Rehdera trinervis, and Cochlosperum vitifolium were abundant in many of the plots [13]. In all Costa Rican plots and successional stages, the most abundant species are dispersed by either wind or by animals [13]. Other studies find that the majority of species in Costa Rican TDF sites have a monoecy breeding system [47]. Of the animals, in Santa Rosa National Park, birds were found to disperse the highest number of individuals and species, followed by other animals, such as bats; however, insects, were the most dominant pollinators in Santa Rosa National Park [47]. Very little is known about pollinators in other parts of the TDFs; however, given the commonalities between Santa Rosa and other TDF sites, it should be expected that other TDFs across the Americas exhibit similar characteristics.

The factors correlating with species richness also varied depending on site and location. Away from the equator, namely Mexico and Brazil, Bolivia, climatic variables, including precipitation/ 
evapotranspiration, and irradiance have the most significant impact on species diversity and species turnover [78-82]. There is also an indication that the number of dry months negatively correlates with species diversity and turnover in these latitudes [12]. In the equatorial latitudes, soil and stand age dominate the local and regional scale species variation [13]. Secondary forest sites also indicate that late-stage forests can recover tree and liana diversity comparable to primary mature forests [39].

\section{Tropical Dry Forest Response to Variations in Climate}

Over the past century, there has been a rise in global temperature with a reduced range in daily temperature fluctuations [83]. Additionally, precipitation in the mid to high latitudes has increased and decreased in the equatorial areas [83]. These precipitation trends vary on a local and regional scale, however, based on geographic and topographic influences. Temperature and precipitation also vary by year, with large latitudinal variations based on the El Nino Southern Oscillation (ENSO) [6]. There have also been increases in the number of extreme events that have occurred globally, including tropical storms, droughts, and fires [83]. Ecosystems differentially respond to these variations and changes based not only on the individual species but also based on the ecological networks and the relationship of the community to the surrounding abiotic environment [84].

Of the climatic variables, the response to temperature and precipitation has been found to explain the majority of variation between different TDFs sites, with rainfall explaining the majority of the differentiation, followed by temperature $[49,85]$.

\subsection{Temperature}

While temperature has less impact on the variability in phenology, biomass, structure, and successional stages in TDFs compared to precipitation, it does provide a moderating effect $[57,86]$. An example of this moderating effect is the limited range of optimal temperature for photosynthesis to occur in both tropical dry and tropical wet forests $\left(29-32{ }^{\circ} \mathrm{C}\right)$ [87]. The photosynthetic activity of the leaves in trees and lianas decreases if the temperature deviates from this range [87].

Temperature is also critical for succession through the recruitment of new species and plant flowering [88]. The magnitude and timing of flowering and pollen production are directly related to temperature, with warmer temperatures increasing flower production [88,89]. The effect is stronger in wet forests but is still present in seasonally dry tropical forests, with consistent increases in both temperature and flower production since 2000 [89]. Temperature and temperature related variables also accounted for $57 \%$ of the variation in succession (forest structure compared to the fallow age) in TDF sites in Mexico [90].

\subsection{Response to Variation in Precipitation}

Successional stage and flowering regimes are also affected by water availability with corresponding increases in precipitation and the magnitude of flowering and pollen production [88]. Flowering timing is also highly related to the onset of the rainy season in TDFs [88]. Successional stages have a mixed relationship with differences in precipitation. Early successional stages with limited water availability recruit more drought tolerant species but have limited regrowth and sprouting, leading to a slower recovery rate $[66,91,92]$. Proximity to old growth areas also moderates recovery rates, along with the seed dispersal mechanisms (mostly controlled by wind) and species recruitment derived from nearby neighbors [40]. Precipitation regimes or water availability do not significantly change the rate at which species diversity increases in areas, nor the species evenness between different sites [40]; however, sites in Brazil did find that the higher precipitation can offset the damages that anthropogenic alterations cause to species diversity [77]. Additionally, evapotranspiration rates, combined with water deficits, drive tree species assemblages in the Mata Atlantica, TDFs, and Caatinga biomes in Brazil [81].

While species diversity may not be significantly related to precipitation, biomass and water availability are positively correlated. In Bolivia, for example, TDF gross primary productivity (GPP) anomalies have historically (from 1980-2009) been correlated to precipitation anomalies $\left(R^{2}=0.8\right)$ and 
increases in the dry season by one day could decrease GPP by up to 1.2\% [93]. On a global scale, there is a significant decrease in AGB when plots have a longer dry season, with an average reduction of $40 \mathrm{Mg} / \mathrm{ha}$ per additional month in the dry season, although this is highly variable by plot (Figure 4) [28].

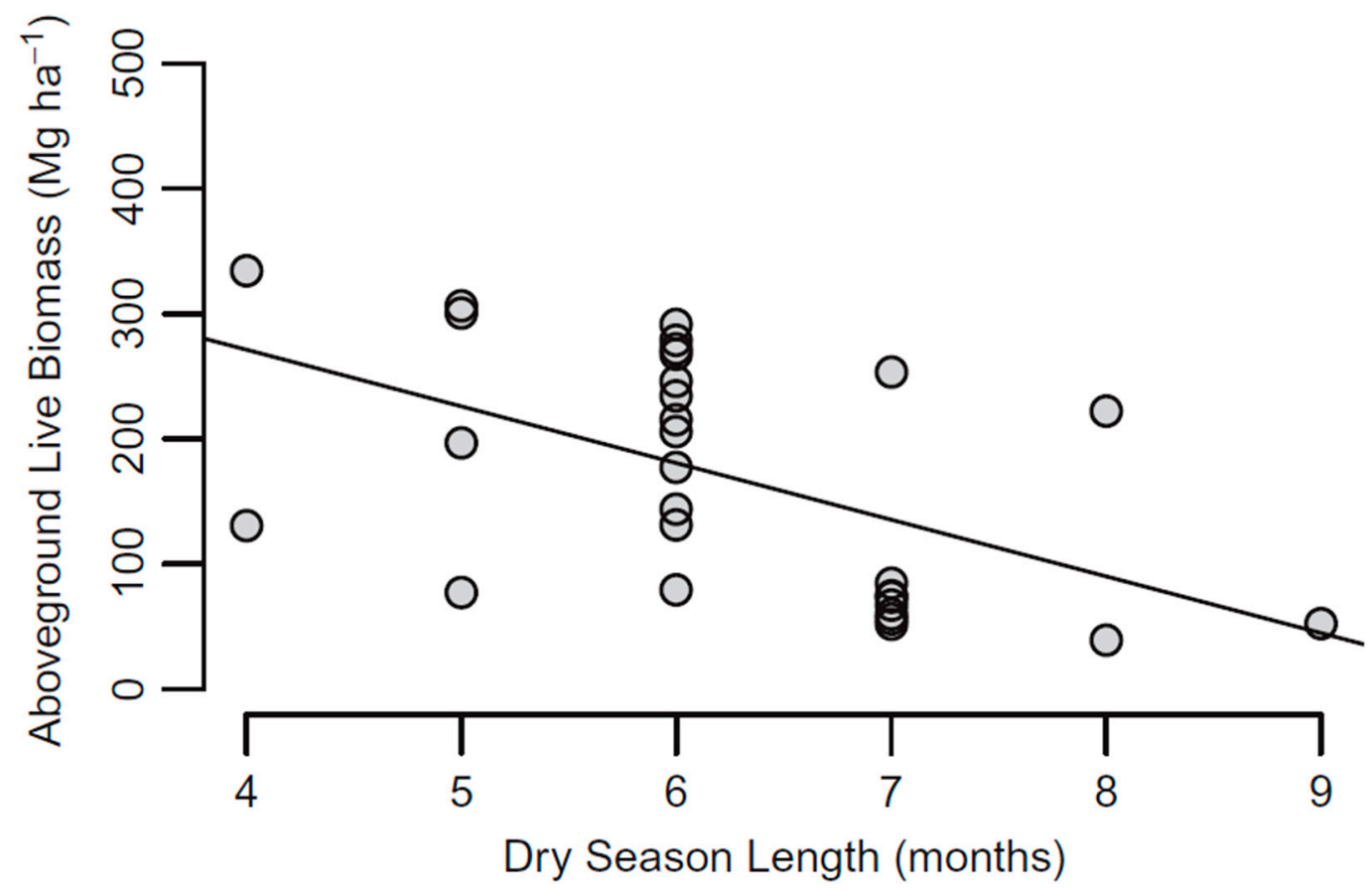

Figure 4. The relationship between the above-ground biomass (AGB) and the length of the dry season with plots from around the globe. The figure is reprinted from Forest Ecology and Management, 276, Becknell et al. Aboveground biomass in mature and secondary seasonally dry tropical forests: A literature review and global synthesis. Forest Ecology and Management 2012. page 91, with permission from Elsevier.

Disturbed TDFs recover quickly, retaining their maximum biomass, species richness, and structural composition within 30-50 years, though their maximum biomass remains smaller than primary forests [13,28,40,67]; however, biomass differentiation can be seen earlier in wetter sites [67]. After twenty years of recovery, secondary forest sites that have a higher annual rainfall have higher biomass, although this saturates above $2500 \mathrm{~mm} /$ year or in tropical wet forests [65,67] (Figure 5). The combination of stand age and mean annual precipitation in TDFs are significantly related to AGB with a logarithmic function [28]. As stands get older, their biomass increases and at 80 years of age, sites that receive $<1000 \mathrm{~mm}$ per year average $100 \mathrm{Mg} / \mathrm{ha}$, ones that have $<1500 \mathrm{~mm} /$ year reach $150 \mathrm{Mg} / \mathrm{ha}$, and ones that have between 1500-2000 mm/year can average $\sim 225 \mathrm{Mg} / \mathrm{ha}$ of biomass [28]. Linearly related to annual biomass growth is the climatic water deficit [65]. Combined with rainfall seasonality and the increases in dry season length having a correlative 1.2\%/day decrease in biomass, the water availability in secondary tropical forests accounts for $59 \%$ of the biomass variation after 20 years of recovery, making it one of the most critical variables [65,93]. For mature forests, an increase in mean annual precipitation of $500 \mathrm{~mm}$ can increase the maximum biomass by $94 \mathrm{Mg} / \mathrm{ha}$ [65]. 


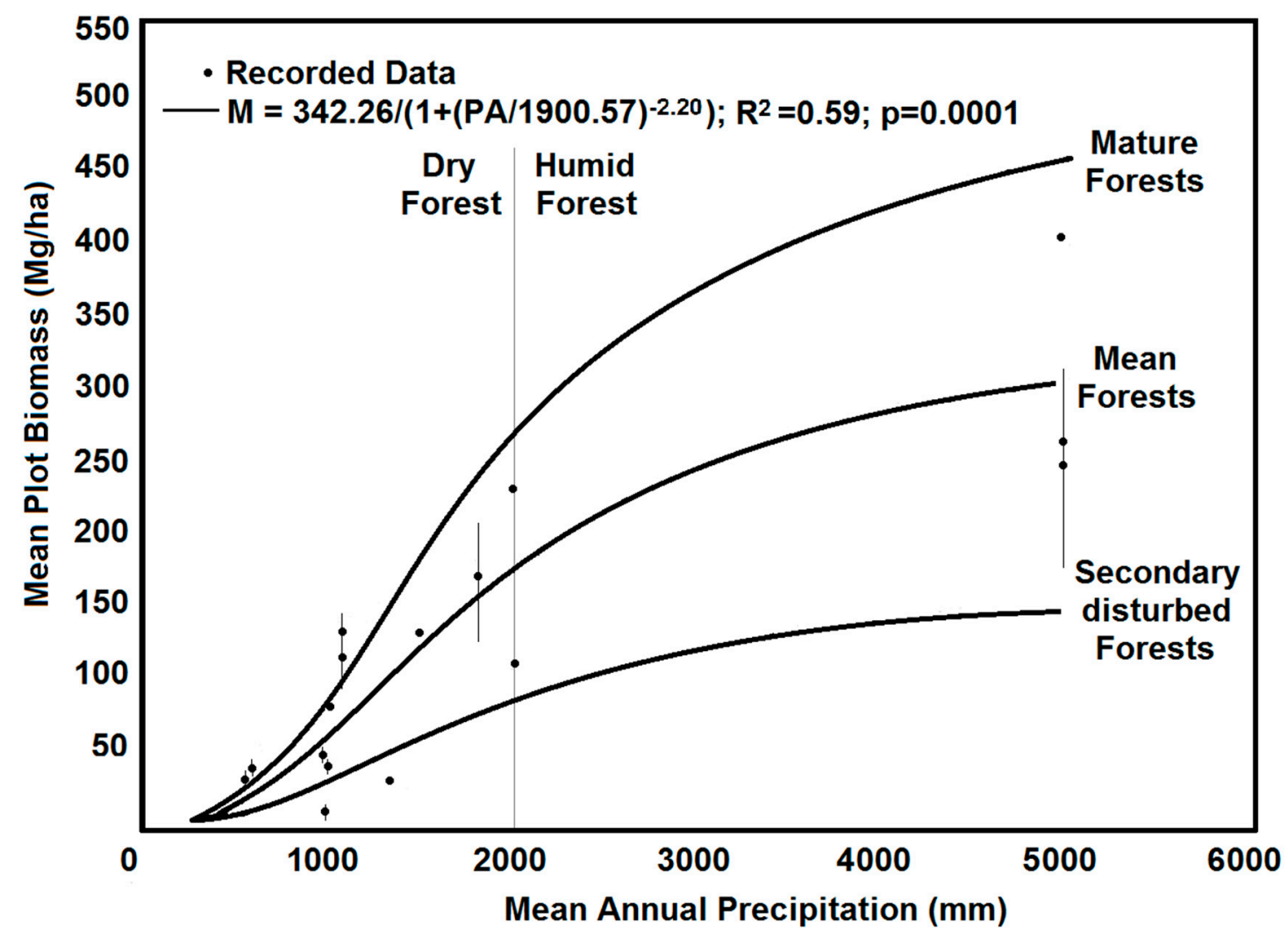

Figure 5. The relationship between mean annual precipitation and forest biomass for primary and secondary forests. The relationship increases and then levels out in the humid forests [67]. The figure is reproduced under CC 4.0 from Navar-Chaidez [67] and includes additional points for Mata Seca, Brazil, and Santa Rosa, Costa Rica collected from Enviro-Net field data.

\subsection{Natural Disturbances}

While not common, natural disturbances are of concern especially as we move into a future with an uncertain climate, where extreme events, such as El Niño Southern Oscillation, are expected to increase in frequency and intensity [6]. Natural disturbances are expected to increase under climate change in terms of frequency and severity, with increases in fires, insect outbreaks, and wind storms already seen in the boreal forest $[94,95]$. In the TDFs, tropical storms, fires, and droughts are of concern.

\subsubsection{Tropical Storms}

In the past decade there have been increases in tropical storms, including Hurricane Otto, the first hurricane to hit the Costa Rican coastline in 2016 (going through the heart of the largest patch of TDF in the country) and Hurricanes Jova (Category 2) and Patricia (Category 4), the first hurricanes to hit the TDF ecosystem on the Mexican Pacific Coast in 2011 and 2015, respectively [96]. These extreme increases in precipitation lead to saturation and super-saturation levels, which negatively impact tree development and water transport and can induce early dormancy [97,98]. Additionally, hurricanes and extreme precipitation events affect the decomposition levels in forests, both during the event and in subsequent years. In the case of the Mexican TDF, a decrease in litterfall decomposition was observed the year following Hurricane Jova. A drop of $\sim 30 \mathrm{mg} /$ day for late-stage forests at Chamela. Further, a reversal of these trends occurred after Patricia [96]. The litterfall did return to normal after two years, however, indicating a level of resiliency in the forests. The vegetation on the coastal plains of Jalisco, Mexico also exhibited a significant decrease in the enhanced vegetation index (EVI) after both hurricanes [99]. Other studies found that deciduous forests showed a higher resilience than semi-deciduous ones [100]. With two hurricanes so close together, however, it was also noted that the 
ecosystem had a higher resistance to the first hurricane compared to the second one despite the high resiliency and rapid return to normality for the litterfall, nutrients, and decomposition rates [96].

Old growth forests in Mexico experience higher severe damage (uprooted, broken trunk, bent trunk; $14 \%)$ compared to secondary forests, while secondary forests have a higher tree mortality $(7 \%)$ in the post-Patricia aftermath [101]. A minor hurricane, such as Jova, halved the number of tree cavities that birds could use for nesting, while larger events had a more substantial effect, shifting the flower and fruit phenology in both deciduous and semi-deciduous areas [100]. Fruit and flower abundance also significantly decreased in the year following Hurricane Jova compared to the one following Hurricane Patricia, and the decrease was more significant for the semi-deciduous forests. Higher fragmentation leads to increased vulnerability and leaves the remaining patches more susceptible to fires post-hurricane. When further extrapolating the damage to the vegetation community and the animals that live there, the hurricanes significantly decreased both bat and small mammal community diversity post-hurricane, but recovery of these populations occurred rapidly [99]. If the frequency of such storms increases in areas that contain TDFs, as we have seen since 2010, there may come the point in time when the resilience of the forests is not substantial enough to mitigate the loss in resistance in both the fauna and flora [102].

Given the increases in the number of these storms impacting the TDFs, their projected rise in the future, and the current lack of information about their impact on TDF resilience in the short and long term, this line of research is increasingly relevant. Differentiating between the types of damage caused by wind, uprooted versus broken trunks or standing dead trees, and their impact on ecological functions should be a focus for research in coming years.

\subsubsection{Fire}

Extreme events are projected to increase on both ends of the spectrum, and fires are predicted to be of growing concern despite no evidence of species shifts compared to the early Holocene when fires were more prevalent [82,96]. It is also important to note, however, that fires are not considered part of the natural Central and South America TDF matrix with few natural fires documented and a much higher prevalence of anthropogenically started fires [103]. Although fires are not considered to be part of the TDF ecosystem naturally, there is evidence to suggest that some species are becoming fire adapted. In the Nicaraguan TDF, there are three main fire adaptations that species exhibit: resistance (low mortality), resprouting (vigorous sprouting post-fire), and recruitment (increased seeding post-fire) [104]. The resilience of TDFs to fire is poorly understood, however, and is a knowledge gap that requires more research. Paleoecological studies could be useful in assessing long-term interactions between natural disturbances, as has been done to assess insect outbreaks in the boreal forest [105].

\subsubsection{Drought}

There is a positive correlation between recovery from drought globally, post-drought temperature, and precipitation. The humid tropics are typically considered to have the highest recovery time; however, the seasonality of rainfall helps the TDF recover quickly. The typical recovery times were $<6$ months, with some pockets of 7-12 months for the ecosystem to fully recover [106]. Drought has also been significantly correlated to the reduction in fine-root and ectomycorrhizal-root biomass [107]. Consistent long-term droughts (6-30 years) have been shown to negatively affect growth, although the amount and duration required is predominantly species based [86]. With shorter droughts mitigated using similar techniques that the forests use in the dry season and early brown down $[86,108]$.

Younger successional stages have indications of stronger regulatory responses compared to late stages during drought [109], with the highest evapotranspiration demand found in 80-year-old forests [109], where leaf area index tends to be higher [36]. Water use efficiency, the ability for an ecosystem to assimilate the same or more carbon [110] is higher in areas such as Mexico and south-central Brazil, where TDFs and savannas are present, (4-9 $\mathrm{g} \mathrm{C} \mathrm{hPa}^{0.5} / \mathrm{kg} \mathrm{H}_{2} \mathrm{O}$ ) compared to the 
tropical wet forests, such as the Amazon (0-3 $\left.\mathrm{g} \mathrm{C} \mathrm{hPa}^{0.5} / \mathrm{kg} \mathrm{H}_{2} \mathrm{O}\right)$ [111]. Under drought conditions, the water use efficiency of TDFs is expected to increase by as much as $38 \%$ compared to average years [93].

\section{Resilience under Climatic Change}

The IPCC fourth report predicted by the end of the XXI century that there would be high rates of extinction, with savanna and drought tolerant vegetation replacing tropical forests. Increases in extreme events will exacerbate this transition. The fifth IPCC report goes further, predicting changes in rainfall, temperature, seasonality, reductions in biodiversity and loss of species even within protected areas [85]; however, global and regional climatic models cannot agree on the scope of climatic change within the TDF habitat. There is a clear consensus that temperatures in the TDFs will increase, but the magnitude of change ranges from $1.5^{\circ} \mathrm{C}$ to $6{ }^{\circ} \mathrm{C}[85,112]$ and may be moderated by the successional stage, with late-stage forests removing up to $120 \mathrm{~W} / \mathrm{m}^{2}$ of heat energy [113]. Land surface temperature, which drives this forest-atmosphere energy exchange, has been studied at the Santa Rosa National Park Environmental Monitoring Super Site [33] and been found to be dependent on the successional stage, with the highest surface temperature found in early stage forests. Precipitation models do not have any prediction consistency with drops of $10 \%-15 \%$ in the Argentinian Chaco up to $50 \%$ in Costa Rica or increased precipitation up to $50 \%$ in the same regions [86,114-116].

Based on the information above, Central and South America TDFs are resilient to the current climatic conditions and this resilience likely to continue, even as the climate warms. The species in the TDF may be slightly altered to include more drought-adapted when they go through successional changes, and there will be a reduction in the biomass currently in mature forests if reduced rainfall occurs; however, these changes will be well within the range of current phenotypic variation, and the phenological cycles, structure, and successional paths will be maintained. Under extreme precipitation scenarios, TDFs are more resilient to drought, with the ability to within decadal-scale droughts, compared to increased precipitation $[86,106,117]$. These projections of resilience also do not take into account a large part of the TDF matrix, human alteration, which may increase pressure on the ecosystem to provide services and space for communities. These pressures could increase rates of deforestation and fragmentation, further exacerbating any apparent changes to climate, and also further increasing temperatures and thereby decreasing the water availability for remaining fragments. Forest management practices, including legislative protection, payments for ecosystem services, and community-based management systems may help reduce these anthropogenic pressures [26].

\section{Conclusions}

Overall, we find that across the entire Neotropical dry forest literature, the forest structure has a longitudinal gradient with increasing basal area in the west. However, phenological cycles, biodiversity, and above-ground biomass all have latitudinal gradients with equatorial regions experiencing higher AGB and biodiversity, less deciduousness, and longer growing seasons. There are local-scale variations in the structure, species composition, liana density, and phenologic characteristics, which are modified by slope, elevation, level of disturbance, and rainfall. The phenological cycles across the continent and the impact of species composition on resilience are poorly understood, and require improved research for proper generalizations.

The TDFs require optimal temperatures for growth, rapid successional development, and consistent flowering times. Variations in precipitation do not impact forest ecological processes as much, with drier areas recruiting more drought tolerant species and flowering later to accommodate this lack of water. Droughts are required on a decadal time scale to damage the ecological functioning of TDF permanently. Floods and tropical storms, however, have greater impacts on the resilience of the TDF. Unfortunately, given the relatively recent occurrence of these disasters impacting TDFs, there is very little research into the full interactions between these disturbances and the ecosystem. This lack of research is important to understand for climate change scenarios, though there is no agreement between models on the direction or magnitude of changes in the Central and South American climates, 
even under consistent emission scenarios. Even if model projections which suggest dry areas will become even more water limited are realized, the biomass response of forests indicates that it will be resilient under these conditions, with changes to more drought tolerant species assemblages and reductions in biomass.

Overall, increasing research needs to be presented on the impacts of tropical storms and flooding on TDFs. The impact of increasing soil saturation on TDF structure, biomass, phenology, and succession is also not well understood, however, and remains a large gap as we approach a time of climatic volatility. There are also gaps in long-term paleoecological studies related to the impact of non-linear forest growth on ecosystem structure and disturbance recovery. Best practices in forest management and legislation under climate change scenarios is also crucial for a holistic understanding of forest resilience, and different practices must be tested and assessed. The role that plant functional type plays in resilience and how it changes under climate change has not been studied and is essential for a comprehensive analysis of future TDF resilience. Finally, understanding of how effectively TDF plants use water is critical when projecting future precipitation changes.

Additionally, within the literature, there remains a severe bias in the location of studies, despite the increase in remote sensing papers about the TDF. Mexico, Costa Rica, and Brazil comprise the majority of the body of TDF literature in Central and South America, leading large gaps in TDF response information in the other 15 countries that house this ecosystem. Further, there is also a significant bias of research between continental and Caribbean dry forests and old and neotropical TDFs. Integrating in situ localized TDF response with regional, remote sensing, carbon flux systems, and modeling data is another crucial step to take within the research, as is incorporating structurally based information from light detection and ranging (LiDAR) and associated systems with spectrally based modeling infrastructure. Finally, direct resilience studies under climate change, with both in situ and remote sensing methodologies, will be an essential step for research to take to directly and concretely determine where these forests are resilient, and where they are not. Defining these locations can also assist in determining if there are intervention strategies that can be used to help preserve this biodiverse ecosystem.

Funding: This research was funded by NSERC CGS-D and Alberta Innovates GSS. We also acknowledge funding support from the Natural Science and Engineering Research Council of Canada, NSERC-Discovery, and the Inter-American Institute, grant number CRN3 025.

Acknowledgments: The authors would also like to acknowledge the support provided by the University of Alberta.

Conflicts of Interest: The authors declare no conflict of interest. The funders had no role in the design of the study; in the collection, analyses, or interpretation of data; in the writing of the manuscript, or in the decision to publish the results.

\section{References}

1. Magrin, G.; Marengo, J.; Boulanger, J.P.; Buckeridge, M.S.; Castellanos, E.; Poveda, G.; Scarano, F.R.; Vicuña, S. Central and South America. In Climate Change 2014: Impacts, Adaptation and Vulnerability. Contribution of Working Group II to the Fifth Assessment Report of the Intergovernmental Panel on Climate Change; Barros, V.R., Field, C.B., Dokken, D.J., Mastrandrea, M.D., Mach, K.J., Bilir, T.E., Chatterjee, M., Ebi, K.L., Estrada, Y.O., Genova, R.C., Eds.; Cambridge University Press: Cambridge, UK, 2014.

2. Yamamoto, L.; Serraglio, D.A.; Cavedon-Capdeville, F.S. Human mobility in the context of climate change and disasters: A South American approach. Int. J. Clim. Chang. Strateg. Manag. 2018, 10, 65-85. [CrossRef]

3. Thiede, B.; Gray, C.; Mueller, V. Climate variability and inter-provincial migration in South America, 1970-2011. Glob. Environ. Chang. 2016, 41, 228-240. [CrossRef]

4. Pivetta, M. 50 Anos de Calamidades na América do Sul. Revista Pesquisa FAPESP 2016, 241, $62-65$.

5. Bender, M.A.; Knutson, T.R.; Tuleya, R.E.; Sirutis, J.J.; Vecchi, G.A.; Garner, S.T.; Held, I.M. Modeled Impact of Anthropogenic Warming on the Frequency of Intense Atlantic Hurricanes. Science 2010, 327, 454-458. [CrossRef] 
6. Cai, W.; Santoso, A.; Wang, G.; Yeh, S.-W.; An, S.-I.; Cobb, K.M.; Collins, M.; Guilyardi, E.; Jin, F.-F.; Kug, J.-S. ENSO and greenhouse warming. Nat. Clim. Chang. 2015, 5, 849. [CrossRef]

7. Wright, S.J. Tropical forests in a changing environment. Trends Ecol. Evol. 2005, 20, 553-560. [CrossRef]

8. Miles, L.; Newton, A.C.; DeFries, R.S.; Ravilious, C.; May, I.; Blyth, S.; Kapos, V.; Gordon, J.E. A global overview of the conservation status of tropical dry forests. J. Biogeogr. 2006, 33, 491-505. [CrossRef]

9. Quesada, M.; Sanchez-Azofeifa, G.A.; Alvarez-Añorve, M.; Stoner, K.E.; Avila-Cabadilla, L.; Calvo-Alvarado, J.; Castillo, A.; Espírito-Santo, M.M.; Fagundes, M.; Fernandes, G.W.; et al. Succession and management of tropical dry forests in the Americas: Review and new perspectives. For. Ecol. Manag. 2009, 258, 1014-1024. [CrossRef]

10. Buzzard, V.; Hulshof, C.M.; Birt, T.; Violle, C.; Enquist, B.J. Re-growing a tropical dry forest: Functional plant trait composition and community assumble during succession. Funct. Ecol. 2016, 30, 1006-1013. [CrossRef]

11. Banda, R.K.; Delgado-Salinas, A.; Dexter, K.G.; Linares-Palomino, R.; Oliveira-Filho, A.; Prado, D.; Pullan, M.; Quintana, C.; Riina, R.; Rodriguez, M.G.M.; et al. Plant diversity patterns in neotropical dry forests and their conservation implications. Science 2016, 353, 1383-1387. [CrossRef]

12. Golicher, D.J.; Cayuela, L.; Newton, A.C. Effects of climate change on the potential species richness of mesoamerican forests. Biotropica 2012, 44, 284-293. [CrossRef]

13. Powers, J.S.; Becknell, J.M.; Irving, J.; Pèrez-Aviles, D. Diversity and structure of regenerating tropical dry forests in Costa Rica: Geographic patterns and environmental drivers. For. Ecol. Manag. 2009, 258, 959-970. [CrossRef]

14. Portillo-Quintero, C.A.; Sánchez-Azofeifa, G.A. Extent and conservation of tropical dry forests in the Americas. Biol. Conserv. 2010, 143, 144-155. [CrossRef]

15. Hesketh, M.; Sánchez-Azofeifa, A. A review of remote sensing of tropical dry forests. In Tropical Dry Forests in the Americas: Ecology, Conservation, and Management; Sánchez-Azofeifa, A., Powers, J.S., Fernandes, G.W., Quesada, M., Eds.; CRC Press: Boca Raton, FL, USA, 2013; pp. 80-98. [CrossRef]

16. Sánchez-Azofeifa, G.A.; Quesada, M.; Rodríguez, J.P.; Nassar, J.M.; Stoner, K.E.; Castillo, A.; Garvin, T.; Zent, E.L.; Calvo-Alvarado, J.C.; Kalacska, M.E.R.; et al. Research Priorities for Neotropical Dry Forests. Biotropica 2005, 37, 477-485. [CrossRef]

17. Kennard, D.K. Secondary forest succession in a tropical dry forest: Patterns of development across a 50-year chronosequence in lowland Bolivia. J. Trop. Ecol. 2002, 18, 53-66. [CrossRef]

18. Hansen, M.C.; Stehman, S.V.; Potapov, P.V. Quantification of global gross forest cover loss. Proc. Natl. Acad. Sci. USA 2010, 107, 8650-8655. [CrossRef]

19. Coelho, P.A.; Santos, P.F.; de Paiva Paula, E.; Apgaua, D.M.G.; Madeira, B.G.; Menino, G.C.d.O.; Nunes, Y.R.F.; Santos, R.M.; Tng, D.Y.P. Tree succession across a seasonally dry tropical forest and forest-savanna ecotone in northern Minas Gerais, Brazil. J. Plant Ecol. 2016, 10, 858-868. [CrossRef]

20. Fajardo, L.; Gonzalez, V.; Nassar, J.M.; Lacabana, P.; Portillo, Q.C.A.; Carrasquel, F.; Rodriguez, J.P. Tropical Dry Forests of Venezuela: Characterization and Current Conservation Status1. Biotropica 2005, 37, 531-546. [CrossRef]

21. Portillo-Quintero, C.; Sanchez-Azofeifa, A.; Calvo-Alvarado, J.; Quesada, M.; Do Espirito Santo, M.M. The role of tropical dry forests for biodiversity, carbon and water conservation in the neotropics: Lessons learned and opportunities for its sustainable management. Reg. Environ. Chang. 2015, 15, 1039-1049. [CrossRef]

22. Sanchez-Azofeifa, G.A.; Kalacska, M.; Quesada, M.; Calvo-Alvarado, J.C.; Nassar, J.M.; Rodriguez, J.P. Need for Integrated Research for a Sustainable Future in Tropical Dry Forests. Conserv. Biol. 2005, 19, $285-286$. [CrossRef]

23. Calvo-Rodriguez, S.; Sanchez-Azofeifa, A.G.; Duran, S.M.; Espirito-Santo, M.M. Assessing ecosystem services in Neotropical dry forests: A systematic review. Environ. Conserv. 2017, 44, 34-43. [CrossRef]

24. Garaglio, M.A.; Sampaio, E.V.d.S.B.; Cestaro, L.A.; Kageyama, P.Y. Uso Sustentável e Conservação dos Recursos Florestais da Caatinga; Serviço Florestal Brasileiro: Brasilia, Brazil, 2010; p. 368.

25. Robalino, J.; Pfaff, A.; Villalobos, L. Heterogeneous Local Spillovers from Protected Areas in Costa Rica. J. Assoc. Environ. Resour. Econ. 2017, 4, 795-820. [CrossRef]

26. Stan, K.; Sanchez-Azofeifa, A. Deforestation and secondary growth in Costa Rica along the path of development. Reg. Environ. Chang. 2019, 19, 587-597. [CrossRef] 
27. Porter-Bolland, L.; Ellis, E.A.; Guariguata, M.R.; Ruiz-Mallén, I.; Negrete-Yankelevich, S.; Reyes-García, V. Community managed forests and forest protected areas: An assessment of their conservation effectiveness across the tropics. For. Ecol. Manag. 2012, 268, 6-17. [CrossRef]

28. Becknell, J.M.; Kissing Kucek, L.; Powers, J.S. Aboveground biomass in mature and secondary seasonally dry tropical forests: A literature review and global synthesis. For. Ecol. Manag. 2012, 276, 88-95. [CrossRef]

29. Allen, K.; Dupuy, J.M.; Gei, M.; Hulshof, C.; Medvigy, D.; Pizano, C.; Salgado Negret, B.; Smith, C.; Trierweiler, A.; Van Bloem, S.; et al. Will seasonally dry tropical forests be sensitive or resistant to future changes in rainfall regimes? Environ. Res. Lett. 2017, 12, 023001. [CrossRef]

30. Grebner, D.L.; Bettinger, P.; Siry, J.P. Chapter 10-Forest Dynamics. In Introduction to Forestry and Natural Resources; Grebner, D.L., Bettinger, P., Siry, J.P., Eds.; Academic Press: Cambridge, MA, USA, 2013; pp. $243-254$. [CrossRef]

31. Ma, L.; Lian, J.; Lin, G.; Cao, H.; Huang, Z.; Guan, D. Forest dynamics and its driving forces of sub-tropical forest in South China. Sci. Rep. 2016, 6, 22561. [CrossRef]

32. Li, W.; Cao, S.; Campos-Vargas, C.; Sanchez-Azofeifa, A. Identifying tropical dry forests extent and succession via the use of machine learning techniques. Int. J. Appl. Earth Observ. Geoinf. 2017, 63, 196-205. [CrossRef]

33. Cao, S.; Sanchez-Azofeifa, A. Modeling seasonal surface temperature variations in secondary tropical dry forests. Int. J. Appl. Earth Observ. Geoinf. 2017, 62, 122-134. [CrossRef]

34. Johnson, E.A.; Miyanishi, K. Testing the assumptions of chronosequences in succession. Ecol. Lett. 2008, 11, 419-431. [CrossRef]

35. Madeira, B.G.; Espírito-Santo, M.M.; Neto, S.D.Â.; Nunes, Y.R.F.; Arturo Sánchez Azofeifa, G.; Wilson Fernandes, G.; Quesada, M. Changes in tree and liana communities along a successional gradient in a tropical dry forest in south-eastern Brazil. Plant Ecol. 2009, 201, 291-304. [CrossRef]

36. Kalacska, M.E.R.; Sánchez-Azofeifa, G.A.; Calvo-Alvarado, J.C.; Rivard, B.; Quesada, M. Effects of Season and Successional Stage on Leaf Area Index and Spectral Vegetation Indices in Three Mesoamerican Tropical Dry Forests. Biotropica 2005, 37, 486-496. [CrossRef]

37. Chazdon, R.L.; Letcher, S.G.; Van Breugel, M.; Martínez-Ramos, M.; Bongers, F.; Finegan, B. Rates of change in tree communities of secondary Neotropical forests following major disturbances. Philos. Trans. R. Soc. B Biol. Sci. 2007, 362, 273-289. [CrossRef]

38. Martínez-Ramos, M.; Balvanera, P.; Arreola Villa, F.; Mora, F.; Maass, J.M.; Maza-Villalobos Méndez, S. Effects of long-term inter-annual rainfall variation on the dynamics of regenerative communities during the old-field succession of a neotropical dry forest. For. Ecol. Manag. 2018, 426, 91-100. [CrossRef]

39. Hernández-Ramírez, A.M.; García-Méndez, S. Diversidad, estructura y regeneración de la selva tropical estacionalmente seca de la Península de Yucatán, México. Revista de Biología Tropical 2015, 63, 603-616. [CrossRef]

40. Derroire, G.; Balvanera, P.; Castellanos-Castro, C.; Decocq, G.; Kennard, D.K.; Lebrija-Trejos, E.; Leiva, J.A.; Odén, P.-C.; Powers, J.S.; Rico-Gray, V.; et al. Resilience of tropical dry forests-A meta-analysis of changes in species diversity and composition during secondary succession. Oikos 2016, 125, 1386-1397. [CrossRef]

41. Singh, K.; Kushwaha, C. Emerging paradigms of tree phenology in dry tropics. Curr. Sci. 2005, 89, 964-975.

42. Wright, S.J.; Calderón, O. Seasonal, El Niño and longer term changes in flower and seed production in a moist tropical forest. Ecol. Lett. 2006, 9, 35-44. [CrossRef]

43. Lebrija-Trejos, E.; Bongers, F.; Pérez-García, E.A.; Meave, J.A. Successional change and resilience of a very dry tropical deciduous forest following shifting agriculture. Biotropica 2008, 40, 422-431. [CrossRef]

44. Brienen, R.J.W.; Lebrija-Trejos, E.; Zuidema, P.A.; Martínez-Ramos, M. Climate-growth analysis for a Mexican dry forest tree shows strong impact of sea surface temperatures and predicts future growth declines. Glob. Chang. Biol. 2010, 16, 2001-2012. [CrossRef]

45. Kalacska, M.; Sanchez-Azofeifa, G.A.; Calvo-Alvarado, J.C.; Quesada, M.; Rivard, B.; Janzen, D.H. Species composition, similarity and diversity in three successional stages of a seasonally dry tropical forest. For. Ecol. Manag. 2004, 200, 227-247. [CrossRef]

46. Castillo-Núñez, M.; Sánchez-Azofeifa, G.A.; Croitoru, A.; Rivard, B.; Calvo-Alvarado, J.; Dubayah, R.O. Delineation of secondary succession mechanisms for tropical dry forests using LiDAR. Remote Sens. Environ. 2011, 115, 2217-2231. [CrossRef] 
47. Hilje, B.; Calvo-Alvarado, J.; Jiménez-Rodríguez, C.; Sánchez-Azofeifa, A. Tree Species Composition, Breeding Systems, and Pollination and Dispersal Syndromes in Three Forest Successional Stages in a Tropical Dry Forest in Mesoamerica. Trop. Conserv. Sci. 2015, 8, 76-94. [CrossRef]

48. Jaramillo, V.J.; Kauffman, J.B.; Renteria-Rodriguez, L.; Cummings, D.L.; Ellingson, L.J. Biomass, Carbon, and Nitrogen Pools in Mexican Tropical Dry Forest Landscapes. Ecosystems 2003, 6, 609-629. [CrossRef]

49. Vilanova, E.; Ramirez-Angulo, H.; Torres-Lezama, A.; Aymard, G.; Gamez, L.; Duran, C.; Hernandez, L.; Herrera, R.; van der Heijden, G.; Phillips, O.L.; et al. Environmental drivers of forest structure and stem turnover across Venezuelan tropical forests. PLoS ONE 2018, 13, e0198489. [CrossRef] [PubMed]

50. Peña-Claros, M.; Poorter, L.; Alarcón, A.; Blate, G.; Choque, U.; Fredericksen, T.S.; Justiniano, M.J.; Leaño, C.; Licona, J.C.; Pariona, W.; et al. Soil Effects on Forest Structure and Diversity in a Moist and a Dry Tropical Forest. Biotropica 2012, 44, 276-283. [CrossRef]

51. Durán, S.M.; Sánchez-Azofeifa, G.A.; Rios, R.S.; Gianoli, E. The relative importance of climate, stand variables and liana abundance for carbon storage in tropical forests. Glob. Ecol. Biogeogr. 2015, 24, 939-949. [CrossRef]

52. Schnitzer, S.A.; Bongers, F. Increasing liana abundance and biomass in tropical forests: Emerging patterns and putative mechanisms. Ecol. Lett. 2011, 14, 397-406. [CrossRef] [PubMed]

53. Kalacska, M.; Sanchez-Azofeifa, G.A.; Rivard, B.; Calvo-Alvarado, J.C.; Quesada, M. Baseline assessment for environmental services payments from satellite imagery: A case study from Costa Rica and Mexico. J. Environ. Manag. 2008, 88, 348-359. [CrossRef]

54. Dewalt, S.J.; Schnitzer, S.A.; Chave, J.; Bongers, F.; Burnham, R.J.; Cai, Z.; Chuyong, G.; Clark, D.B.; Ewango, C.E.N.; Gerwing, J.J.; et al. Annual Rainfall and Seasonality Predict Pan-tropical Patterns of Liana Density and Basal Area. Biotropica 2010, 42, 309-317. [CrossRef]

55. Schnitzer, S.A. A mechanistic explanation for global patterns of liana abundance and distribution. Am. Nat. 2005, 166, 262-276. [CrossRef]

56. Van Der Heijden, G.M.F.; Phillips, O.L. What controls liana success in Neotropical forests? Glob. Ecol. Biogeogr. 2008, 17, 372-383. [CrossRef]

57. Reich, P.B.; Borchert, R. Water stress and tree phenology in a tropical dry forest in the lowlands of Costa Rica. J. Ecol. 1994, 72, 61-74. [CrossRef]

58. Rankine, C.; Sánchez-Azofeifa, G.A.; Guzmán, J.A.; Espirito-Santo, M.M.; Sharp, I. Comparing MODIS and near-surface vegetation indexes for monitoring tropical dry forest phenology along a successional gradient using optical phenology towers. Environ. Res. Lett. 2017, 12. [CrossRef]

59. Elliott, S.; Baker, P.J.; Borchert, R. Leaf flushing during the dry season: The paradox of Asian monsoon forests. Glob. Ecol. Biogeogr. 2006, 15, 248-257. [CrossRef]

60. Hulshof, C.M.; Martínez-Yrízar, A.; Burquez, A.; Boyle, B.; Enquist, B.J. Plant functional trait variation in tropical dry forests: A review and synthesis. In Tropical Dry Forests in the Americas: Ecology, Conservation, and Management; Sánchez-Azofeifa, A., Powers, J.S., Fernandes, G.W., Quesada, M., Eds.; CRC Press: Boca Raton, FL, USA, 2013; pp. 129-140. [CrossRef]

61. Lopezaraiza-Mikel, M.; Quesada, M.; Álvarez-Añorve, M.; Ávila-Cabadilla, L.; Martén-Rodríguez, S.; Calvo-Alvarado, J.; do Espírito-Santo, M.M.; Fernandes, G.W.; Sánchez-Azofeifa, A.; de Jesús Aguilar-Aguilar, M. Phenological patterns of tropical dry forests along latitudinal and successional gradients in the neotropics. In Tropical Dry Forests in the Americas: Ecology, Conservation, and Management; Sánchez-Azofeifa, A., Powers, J.S., Fernandes, G.W., Quesada, M., Eds.; CRC Press: Boca Raton, FL, USA, 2013; pp. 113-140. [CrossRef]

62. Castro, S.M.; Sanchez-Azofeifa, G.A.; Sato, H. Effect of drought on productivity in a Costa Rican tropical dry forest. Environ. Res. Lett. 2018, 13. [CrossRef]

63. Pezzini, F.F.; Ranieri, B.D.; Brandão, D.O.; Fernandes, G.W.; Quesada, M.; Espírito-Santo, M.M.; Jacobi, C.M. Changes in tree phenology along natural regeneration in a seasonally dry tropical forest. Plant Biosyst. Int. J. Deal. Asp. Plant Biol. 2014, 148, 965-974. [CrossRef]

64. Ravindrath, N.H.; Ostwald, M. Carbon Inventory Methods: Handbook for Greenhouse Gas Inventory, Carbon Mitigation and Roundwood Production Projects; Beninston, M., Ed.; Springer: New York, NY, USA, 2008; p. 315. [CrossRef]

65. Poorter, L.; Bongers, F.; Aide, T.M.; Almeyda Zambrano, A.M.; Balvanera, P.; Becknell, J.M.; Boukili, V.; Brancalion, P.H.; Broadbent, E.N.; Chazdon, R.L.; et al. Biomass resilience of Neotropical secondary forests. Nature 2016, 530, 211-214. [CrossRef] 
66. Rozendaal, D.M.A.; Chazdon, R.L.; Arreola-Villa, F.; Balvanera, P.; Bentos, T.V.; Dupuy, J.M.; Hernández-Stefanoni, J.L.; Jakovac, C.C.; Lebrija-Trejos, E.E.; Lohbeck, M.; et al. Demographic Drivers of Aboveground Biomass Dynamics During Secondary Succession in Neotropical Dry and Wet Forests. Ecosystems 2016, 20, 340-353. [CrossRef]

67. Navar Chaidez, J.D.J. The Spatial Distribution of Aboveground Biomass in Tropical Forests of Mexico. Trop. Subtrop. Agroecosyst. 2010, 13, 10.

68. De Jong, B.H.; Gutiérrez, L.I.; de la Rosa, J.A.A. Advances of Mexico in Preparing for REDD: UNFCCC Workshop on Methodological Issues Relating to Reducing Emissions from Deforestation and Forest Degradation in Developing Countries; UNFCCC: Tokyo, Japan, 2008.

69. Houghton, R.A. The annual net flux of carbon to the atmosphere from changes in land use 1850-1990. Tellus B 1999, 51, 298-313. [CrossRef]

70. Defries, R.S.; Houghton, R.A.; Hansen, M.C.; Field, C.B.; Skole, D.; Townshend, J. Carbon emissions from tropical deforestation and regrowth based on satellite observations for the 1980s and 1990s. Proc. Natl. Acad. Sci. USA 2002, 99, 14256-14261. [CrossRef] [PubMed]

71. Brown, S. Estimating Biomass and Biomass Change of Tropical Forests: A Primer; Food \& Agriculture Org.: Rome, Italy, 1997; Volume 134.

72. Achard, F.; Eva, H.D.; Mayaux, P.; Stibig, H.-J.; Belward, A. Improved estimates of net carbon emissions from land cover change in the tropics for the 1990s. Glob. Biogeochem. Cycles 2004, 18, GB2008. [CrossRef]

73. IPCC. IPCC Guidelines for National Greenhouse Gas Inventories-A Primer; Institute for Global Environmental Strategires: Hayama, Japan, 2006.

74. Corona-Núñez, R.O.; Mendoza-Ponce, A.; López-Martínez, R. Model selection changes the spatial heterogeneity and total potential carbon in a tropical dry forest. For. Ecol. Manag. 2017, 405, 69-80. [CrossRef]

75. Montoro-Girona, M.; Morin, H.; Lussier, J.M.; Walsh, D. Radial growth response of black spruce stands ten years after experimental shelterwoods and seed-tree cuttings in borel forest. Forests 2016, 7, 20. [CrossRef]

76. Montoro-Girona, M.; Rossi, S.; Lussier, J.M.; Walsh, D.; Morin, H. Understanding tree growth responses after partial cuttings: A new approach. PLoS ONE 2016, 12, e0172653. [CrossRef] [PubMed]

77. Rito, K.F.; Arroyo-Rodríguez, V.; Queiroz, R.T.; Leal, I.R.; Tabarelli, M.; Norden, N. Precipitation mediates the effect of human disturbance on the Brazilian Caatinga vegetation. J. Ecol. 2017, 105, 828-838. [CrossRef]

78. Trejo, I.; Dirzo, R. Floristic diversity of Mexican seasonally dry tropical forests. Biodivers. Conserv. 2002, 11, 2063-2084. [CrossRef]

79. Segura, G.; Balvanera, P.; Durán, E.; Pérez, A. Tree community structure and stem mortality along a water availability gradient in a Mexican tropical dry forest. Plant Ecol. 2002, 169, 259-271. [CrossRef]

80. Vargas-Rodriguez, Y.L.; Vazquez-Garcia, J.A.; Williamson, G.B. Environmental correlates of tree and seedling-sapling distributions in a Mexican tropical dry forest. Plant Ecol. 2005, 180, 117-134. [CrossRef]

81. Saiter, F.Z.; Eisenlohr, P.V.; Barbosa, M.R.V.; Thomas, W.W.; Oliveira-Filho, A.T. From evergreen to deciduous tropical forests: How energy-water balance, temperature, and space influence the tree species composition in a high diversity region. Plant Ecol. Divers. 2015, 9, 45-54. [CrossRef]

82. Power, M.J.; Whitney, B.S.; Mayle, F.E.; Neves, D.M.; de Boer, E.J.; Maclean, K.S. Fire, climate and vegetation linkages in the Bolivian Chiquitano seasonally dry tropical forest. Philos. Trans. R. Soc. Lond. B Biol. Sci. 2016, 371. [CrossRef] [PubMed]

83. Easterling, D.R.; Meehl, G.A.; Parmesan, C.; Changnon, S.A.; Karl, T.R.; Mearns, L.O. Climate Extremes: Observations, Modeling, and Impacts. Science 2000, 289, 2068-2074. [CrossRef] [PubMed]

84. Walther, G.R. Community and ecosystem responses to recent climate change. Philos. Trans. R. Soc. B Biol. Sci. 2010, 365, 2019-2024. [CrossRef]

85. Mendivelso, H.A.; Camarero, J.J.; Gutiérrez, E.; Zuidema, P.A. Time-dependent effects of climate and drought on tree growth in a Neotropical dry forest: Short-term tolerance vs. long-term sensitivity. Agric. For. Meteorol. 2014, 188, 13-23. [CrossRef]

86. Álvarez-Dávila, E.; Cayuela, L.; González-Caro, S.; Aldana, A.M.; Stevenson, P.R.; Phillips, O.; Cogollo, Á.; Peñuela, M.C.; Von Hildebrand, P.; Jiménez, E.; Melo, O.; et al. Forest biomass density across large climate gradients in northern South America is related to water availability but not with temperature. PLoS ONE 2017, 12, e0171072. [CrossRef] [PubMed] 
87. Slot, M.; Winter, K. In situ temperature response of photosynthesis of 42 tree and liana species in the canopy of two Panamanian lowland tropical forests with contrasting rainfall regimes. New Phytol. 2017, 214, 1103-1117. [CrossRef] [PubMed]

88. Haselhorst, D.S.; Tcheng, D.K.; Moreno, J.E.; Punyasena, S.W. The effects of seasonal and long-term climatic variability on Neotropical flowering phenology: An ecoinformatic analysis of aerial pollen data. Ecol. Inform. 2017, 41, 54-63. [CrossRef]

89. Pau, S.; Wolkovich, E.M.; Cook, B.I.; Nytch, C.J.; Regetz, J.; Zimmerman, J.K.; Joseph Wright, S. Clouds and temperature drive dynamic changes in tropical flower production. Nat. Clim. Chang. 2013, 3, 838-842. [CrossRef]

90. Lebrija-Trejos, E.; Pérez-García, E.A.; Meave, J.A.; Poorter, L.; Bongers, F. Environmental changes during secondary succession in a tropical dry forest in Mexico. J. Trop. Ecol. 2011, 27, 477-489. [CrossRef]

91. McLaren, K.P.; McDonald, M.A. Seedling dynamics after different intensities of human disturbance in a tropical dry limestone forest in Jamaica. J. Trop. Ecol. 2003, 19, 567-578. [CrossRef]

92. Markesteijn, L.; Poorter, L.; Bongers, F.; Paz, H.; Sack, L. Hydraulics and life history of tropical dry forest tree species: Coordination of species' drought and shade tolerance. New Phytol. 2011, 191, 480-495. [CrossRef]

93. Seiler, C.; Hutjes, R.W.A.; Kruijt, B.; Quispe, J.; Añez, S.; Arora, V.K.; Melton, J.R.; Hickler, T.; Kabat, P. Modeling forest dynamics along climate gradients in Bolivia. J. Geophys. Res. Biogeosci. 2014, 119, 758-775. [CrossRef]

94. Navarro, L.; Morin, H.; Bergeron, Y.; Girona, M.M. Changes in spatiotemporal patterns of 20th century spruce budworm outbreaks in Eastern Canadian Boreal Forests. Front. Plant Sci. 2018, 9, 1905. [CrossRef]

95. Seidl, R.; Schelhaas, M.J.; Rammer, W.; Verkerk, P.J. Increasing forest disturbances in Europe and their impact on carbon storage. Nat. Clim. Chang. 2014, 4, 806. [CrossRef] [PubMed]

96. Gavito, M.E.; Sandoval-Pérez, A.L.; del Castillo, K.; Cohen-Salgado, D.; Colarte-Avilés, M.E.; Mora, F.; Santibáñez-Rentería, A.; Siddique, I.; Urquijo-Ramos, C. Resilience of soil nutrient availability and organic matter decomposition to hurricane impact in a tropical dry forest ecosystem. For. Ecol. Manag. 2018, 426, 81-90. [CrossRef]

97. Xie, Y.; Wang, X.; Silander, J.A. Deciduous forest responses to temperature, precipitation, and drought imply complex climate change impacts. Proc. Natl. Acad. Sci. USA 2015, 112, 13585-13590. [CrossRef]

98. Kanniah, K.D.; Beringer, J.; Hutley, L.B. Response of savanna gross primary productivity to interannual variability in rainfall: Results of a remote sensing based light use efficiency model. Prog. Phys. Geogr. 2013, 37, 642-663. [CrossRef]

99. Tapia-Palacios, M.A.; García-Suárez, O.; Sotomayor-Bonilla, J.; Silva-Magaña, M.A.; Pérez-Ortíz, G.; Espinosa-García, A.C.; Ortega-Huerta, M.A.; Díaz-Ávalos, C.; Suzán, G.; Mazari-Hiriart, M. Abiotic and biotic changes at the basin scale in a tropical dry forest landscape after Hurricanes Jova and Patricia in Jalisco, Mexico. For. Ecol. Manag. 2018, 426, 18-26. [CrossRef]

100. Renton, K.; Salinas-Melgoza, A.; Rueda-Hernández, R.; Vázquez-Reyes, L.D. Differential resilience to extreme climate events of tree phenology and cavity resources in tropical dry forest: Cascading effects on a threatened species. For. Ecol. Manag. 2018, 426, 164-175. [CrossRef]

101. Jimenez-Rodríguez, D.L.; Alvarez-Añorve, M.Y.; Pineda-Cortes, M.; Flores-Puerto, J.I.; Benítez-Malvido, J.; Oyama, K.; Avila-Cabadilla, L.D. Structural and functional traits predict short term response of tropical dry forests to a high intensity hurricane. For. Ecol. Manag. 2018, 426, 101-114. [CrossRef]

102. Holm, J.A.; Van Bloem, S.J.; Larocque, G.R.; Shugart, H.H. Shifts in biomass and productivity for a subtropical dry forest in response to simulated elevated hurricane disturbances. Environ. Res. Lett. 2017, 12. [CrossRef]

103. Middleton, B.A.; Sanchez-Rojas, E.; Suedmeyer, B.; Michels, A. Fire in a Tropical Dry Forest of Central America: A Natural Part of the Disturbance Regime? Biotropica 1997, 29, 515-517. [CrossRef]

104. Otterstrom, S.M.; Schwartz, M.W.; Velázquez-Rocha, I. Responses to Fire in Selected Tropical Dry Forest Trees. Biotropica 2006, 38, 592-598. [CrossRef]

105. Montoro-Girona, M.; Navarro, L.; Morin, H. A secret hidden in the sediments: Lepidoptera scales. Front. Ecol. Evol. 2018, 6. [CrossRef]

106. Schwalm, C.R.; Anderegg, W.R.; Michalak, A.M.; Fisher, J.B.; Biondi, F.; Koch, G.; Litvak, M.; Ogle, K.; Shaw, J.D.; Wolf, A. Global patterns of drought recovery. Nature 2017, 548, 202. [CrossRef] 
107. Valdes, M.; Asbjornsen, H.; Gomez-Cardenas, M.; Juarez, M.; Vogt, K.A. Drought effects on fine-root and ectomycorrhizal-root biomass in managed Pinus oaxacana Mirov stands in Oaxaca, Mexico. Mycorrhiza 2006, 16, 117-124. [CrossRef] [PubMed]

108. Pau, S.; Okin, G.S.; Gillespie, T.W. Asynchronous response of tropical forest leaf phenology to seasonal and el Nino-driven drought. PLoS ONE 2010, 5, e11325. [CrossRef]

109. Bretfeld, M.; Ewers, B.E.; Hall, J.S. Plant water use responses along secondary forest succession during the 2015-2016 El Nino drought in Panama. New Phytol. 2018, 219, 885-899. [CrossRef]

110. Keenan, T.F.; Hollinger, D.Y.; Bohrer, G.; Dragoni, D.; Munger, J.W.; Schmid, H.P.; Richardson, A.D. Increase in forest water-use efficiency as atmospheric carbon dioxide concentrations rise. Nature 2013, 499, 324-327. [CrossRef]

111. Konings, A.G.; Gentine, P. Global variations in ecosystem-scale isohydricity. Glob. Chang. Biol. 2017, 23, 891-905. [CrossRef]

112. Taylor, M.A.; Centella, A.; Charlery, J.; Bezanilla, A.; Campbell, J.; Borrajero, I.; Stephenson, T.; Nurmohamed, R. The Precis Caribbean Story: Lessons and Legacies. Bull. Am. Meteorol. Soc. 2013, 94, 1065-1073. [CrossRef]

113. Coe, M.T.; Brando, P.M.; Deegan, L.A.; Macedo, M.N.; Neill, C.; Silvério, D.V. The Forests of the Amazon and Cerrado Moderate Regional Climate and Are the Key to the Future. Trop. Conserv. Sci. 2017, 10. [CrossRef]

114. Chadwick, R.; Good, P.; Martin, G.; Rowell, D.P. Large rainfall changes consistently projected over substantial areas of tropical land. Nat. Clim. Chang. 2015, 6, 177-181. [CrossRef]

115. Huang, J.; Yu, H.; Guan, X.; Wang, G.; Guo, R. Accelerated dryland expansion under climate change. Nat. Clim. Chang. 2015, 6, 166-171. [CrossRef]

116. Salazar, A.; Katzfey, J.; Thatcher, M.; Syktus, J.; Wong, K.; McAlpine, C. Deforestation changes land-atmosphere interactions across South American biomes. Glob. Planet. Chang. 2016, 139, 97-108. [CrossRef]

117. Esquivel-Hernández, G.; Sánchez-Murillo, R.; Birkel, C.; Good, S.P.; Boll, J. Hydroclimatic and ecohydrological resistance/resilience conditions across tropical biomes of Costa Rica. Ecohydrology 2017, 10. [CrossRef]

(C) 2019 by the authors. Licensee MDPI, Basel, Switzerland. This article is an open access article distributed under the terms and conditions of the Creative Commons Attribution (CC BY) license (http://creativecommons.org/licenses/by/4.0/). 